\title{
Protistan grazing and viral lysis losses of bacterial carbon production in a large mesotrophic lake (Lake Biwa)
}

\section{$\operatorname{AUTHOR}(\mathrm{S}):$}

Takasu, Hiroyuki; Kunihiro, Tadao; Nakano, Shinichi

\section{CITATION:}

Takasu, Hiroyuki ... [et al]. Protistan grazing and viral lysis losses of bacterial carbon production in a large mesotrophic lake (Lake Biwa). Limnology 2014, 15(3): 257-270

\section{ISSUE DATE:}

2014-08

URL:

http://hdl.handle.net/2433/190411

\section{RIGHT:}

The final publication is available at Springer via http://dx.doi.org/10.1007/s10201-0140431-6; 許諾条件により本文は2015-04-19に公開.; This is not the published version. Please cite only the published version.; この論文は出版社版でありません。引用の際には 出版社版をご確認ご利用ください。 
2 Protistan grazing and viral lysis losses of bacterial carbon production in a large mesotrophic lake (Lake Biwa)

4

5 Hiroyuki Takasu ${ }^{1,2}$, Tadao Kunihiro ${ }^{3,4}$ and Shin-ichi Nakano ${ }^{1 *}$

6

${ }^{1}$ Center for Ecological Research (CER), Kyoto University, Hirano-cho 2 chome, 509-3, Otsu,

Shiga 520-2113, Japan

${ }^{2}$ Present address: Atmosphere and Ocean Research Institute (AORI), The University of Tokyo, 5-1-5 Kashiwanoha, Kashiwa, Chiba 277-8564, Japan

${ }^{3}$ Center for Marine Environmental Studies (CMES), Ehime University, Bunkyo-cho 2-5, Matsuyama 790-8577, Ehime, Japan

${ }^{4}$ Present address: Department of Ecosystems Studies / Department of Marine Microbiology, Royal Netherlands Institute for Sea Research (NIOZ), Korringaweg 7, 4400 AC Yerseke, The Netherlands

*Correspondence to: Shin-ichi Nakano: Mailing address: Center for Ecological Research (CER), Kyoto University, Hirano-cho 2 chome, 509-3, Otsu, Shiga 520-2113, Japan.

Phone and Fax: +81-77-549-8239, +81-77-549-8201

E-mail: nakano@ecology.kyoto-u.ac.jp

Running title: Losses of bacterial carbon production in Lake Biwa

Key words: Bacterial growth, Grazing mortality, Viral-mediated mortality 
24

\section{Abstract}

The grazing and lysis mortality of planktonic bacteria were estimated using the modified dilution method and respiratory quinone (RQ) analysis in mesotrophic Lake Biwa, Japan. The planktonic bacterial assemblages in the lake consisted of various RQs subgroups with different growth and mortality rates. The sum of total bacterial mortalities due to protistan grazing and viral lysis accounted for $96.6 \%$ (range; 89.0 - 107.2\%) of daily total bacterial production. This is the first report which successfully demonstrates a balanced relationship between bacterial production and losses using the modified dilution method in a lake. The growth rates of ubiquinone (UQ)-containing bacteria were faster than those of menaquinone-containing bacteria. Especially, the dominant and fastest-growing bacterial groups in the present study were the bacterial groups containing UQ-8 or UQ-10. The sum of their production and loss accounted for $60 \%$ of carbon fluxes within the microbial loop. Thus, a large portion of the carbon cycling through the bacterial community in Lake Biwa can be explained by the carbon fluxes through dominant bacterial groups. 


\section{Introduction}

In the pelagic environments of freshwater and marine systems, a significant fraction of primary production is consumed by heterotrophic bacteria via dissolved organic matter (DOM) released from phytoplankton (Cole et al. 1988; Ducklow 2000). Protistan grazing and viral lysis are two important determinants of the fate of bacterial biomass (Azam et al. 1983; Proctor and Fuhrman 1991), with different ecological and biogeochemical implications. Protistan grazing transfers bacterial biomass to higher trophic-level organisms via the microbial loop (Azam et al. 1983), whereas viral lysis leads to the recycling of carbon and nutrients, both of which are derived from lysed bacterial biomass and are re-supplied to bacteria (Bratbak et al. 1990; Gobler et al. 1997; Proctor and Fuhrman 1991).

Natural bacterial assemblages consist of various subgroups in terms of ecological and biogeochemical features. The relationship between dynamics of bacterial community structure and variations in carbon cycling within the microbial loop are not well understood in natural aquatic systems, though the results of some ecological models suggest that changes in bacterial community structure can affect the carbon fluxes through bacterial communities (Miki et al. 2008). Only limited attempts have so far been conducted to make simultaneous estimation of grazer-induced and virus-induced bacterial mortality for distinct bacterial groups (Šimek et al. 2001; 2007). Obviously, different mortalities among distinct bacterial groups can influence bacterial community composition. The 'size-selective mortality' for flagellates changes the size distribution of bacterial community (Pernthaler 2005), whereas the 'host-specificity mortality' for viruses changes the bacterial community structure (Thingstad 2000). It is, therefore, important to simultaneously estimate grazing-induced mortality and virus-induced mortality for better understanding on carbon fluxes through bacterial community.

Specific growth and mortality rates of microbial populations can be simultaneously estimated from observed differences in their rates of population growth in a series of 
incubated diluted and undiluted natural water samples (Landry and Hassett 1982; Landry et al. 1984). The dilution technique, originally developed for the estimation of grazing pressure by micro-zooplankton on phytoplankton (Landry and Hassett 1982), is valid to estimate protistan bacterivory (Landry et al. 1984; Trremaine and Mills 1987). Evans et al. (2003) proposed a modified dilution technique to estimate the impacts of protistan grazing and viral lysis on the picoeukaryote Micromonas spp. Their technique was successfully applied to estimate the impact of viral lysis on planktonic bacteria in freshwater lake (Tijidens et al. 2008) and ocean (Taira et al. 2009).

Fluorescence in situ hybridization (FISH) technique as one of the most powerful quantitative molecular approaches has been used for quantifying and visualizing bacterial cells in freshwater and seawater (Pernthaler et al. 1998; Glöckner et al. 1999). The FISH technique is suitable for targeting at specific phylogenetic group levels but less suitable for analysis of the full bacterial community, because quantitative application for analysis of all bacterial groups requires the use of many target-specific probes and also need to optimize its protocol for each target groups (Bouvier and del Giorgio 2003). Despite the superiority of FISH technique-based approaches in terms of phylogenetic identification, respiratory quinone (RQ) analysis has been successfully used to quantify bacterial biomass and to overview bacterial community composition in freshwater (Takasu et al. 2013). Respiratory quinone (RQ), including ubiquinone (UQ) and menaquinone (MK), are electron-transporting compounds in bacterial plasma membranes. Different types of RQ differ in their preference of electron accepters for energy metabolism (Hedrick and White 1986). A bacterial phylum has generally only one dominant molecular species of respiratory quinone (Collins and Jones 1981; Hedrick and White 1986). The RQ analysis provides a less laborious and accurate method for simultaneously determining bacterial carbon biomass and community composition because of the chemical analytical-based method with a standardized quantitative extraction protocol (Hu et al. 1999; Takasu et al., 2013). The modified dilution technique combined with 
RQ analysis provides us quantitative information about carbon fluxes through distinct bacterial groups in complex microbial food web.

Lake Biwa is a large (surface area, $674 \mathrm{~km}^{2}$; water volume, $27.3 \mathrm{~km}^{3}$; watershed area, $3848 \mathrm{~km}^{2}$ ), deep (maximum depth, $104 \mathrm{~m}$ ), mesotrophic and monomictic lake in Japan. Large lakes in the world are generally important freshwater resources (Herdendorf 1990). In addition, large lakes are a precious food production site (Constanza et al. 1997). Net bacterial production in Lake Biwa was estimated as 30\% of primary production (Nagata et al. 1990), and their total consumption (net bacterial production plus respiration) was accounted for 50 to $100 \%$ of the primary production (Nagata et al. 2012). It has been regarded that carbon fluxes through bacterial community are highly active, and that bacteria are a potentially important basis of the pelagic food web in Lake Biwa (Nagata 1990). Thus, elucidating the carbon fluxes through bacterial subgroups is important for our better understanding about carbon cycling in ecosystem of Lake Biwa.

In the present study, we quantified the carbon fluxes through the bacterial community by estimating carbon production and losses calculated from growth and mortality rates of planktonic bacteria in Lake Biwa. We hypothesized that each bacterial group would have different ecological roles within microbial loop. To test this hypothesis, we determined the grazing and lysis mortalities of each bacterial group using the modified dilution technique and RQ analysis. Our data demonstrated that a large portion of the carbon cycling through the bacterial community in Lake Biwa can be explained by the carbon fluxes through dominant bacterial groups.

\section{Materials and Methods}

\section{Dilution experiments}

The dilution experiments were conducted in June and October 2011 and May, June, and July

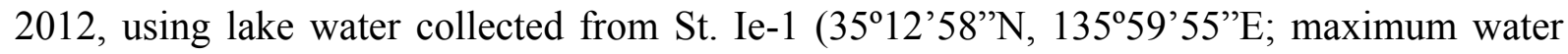


depth $73 \mathrm{~m}$ ) in the pelagic area of the north basin of Lake Biwa, Japan. Approximately $100 \mathrm{~L}$ of lake water was collected from $5 \mathrm{~m}$ depth using a 10-L acryl water sampler. Enumeration of microbes was performed by placing $200 \mathrm{~mL}$ of the water sample in a polypropylene bottle and fixing immediately with glutaraldehyde at a final concentration of $1 \%$. Water samples for the dilution experiments were poured into acid-washed $10-\mathrm{L}$ polyethylene bags or $20-\mathrm{L}$ polyethylene tanks. The lake water was gently filtered through $20 \mu \mathrm{m}$ mesh to remove mesozooplankton, and $50 \mathrm{~L}$ of the filtrate was gravity filtered through $0.2 \mu \mathrm{m}$ filter cartridges (PALL Acropak Supor membrane capsules) and collected into tanks. After the filtration, half of the $0.2 \mu \mathrm{m}$ filtrate was passed through a $30 \mathrm{kDa}$ tangential flow filtration system (Millipore PES membrane) to prepare a virus-free diluent. The $20 \mu \mathrm{m}$ filtrate was diluted in $0.2 \mu \mathrm{m}$ or 30 $\mathrm{kDa}$ diluents to dilution levels of $1.0,0.8,0.4$, and 0.2 , in 5 -L polycarbonate bottles washed with $1.2 \mathrm{M} \mathrm{HCl}$ before use. The bottles were then incubated for 36 to 48 hours at in situ temperatures, in dark conditions. Subsamples for the measurement of RQs were collected into clean polyethylene bags at the beginning ( 0 hours) and end of the incubations.

\section{Enumeration of microbes}

For the enumeration of bacteria, 1 or $2 \mathrm{~mL}$ of the fixed water sample was used. Bacterial cells were counted using an epifluorescence microscope (BX60, Olympus) under ultraviolet excitation by the DAPI (4,6-diamidino-2-phenylindole) method (Porter and Feig 1980) using $0.2 \mu \mathrm{m}$ pore-size black polycarbonate filters (Advantec). At least 300 bacterial cells were counted, and a minimum of 20 fields were randomly selected. Fifteen milliliters of the fixed water sample were used for the enumeration of nanoflagellates, and $0.1 \mathrm{~mL}(1 \mathrm{~mL}$ from the 10x diluted samples with $0.02 \mu \mathrm{m}$ filtered distilled water) was used for the enumeration of viral-like particles (VLP). Heterotrophic nanoflagellates (HNF) and pigmented nanoflagellates (PNF) were counted using epifluorescence microscopy under ultraviolet and green excitation respectively, using the primulin method (Caron 1983), using $0.8 \mu \mathrm{m}$ pore-size black polycarbonate filters (Corning). Cells of PNF were enumerated by 
autofluorescence using an epifluorescence microscope under green excitation. For HNF and PNF counting, a minimum of 100 fields were randomly inspected. VLP were counted using epifluorescence microscopy under blue excitation by the SYBR Green I method (Noble and Fuhrman 1998; Patel et al. 2008), using $0.02 \mu \mathrm{m}$ pore-size Anodisc filters (Whatman). More than 300 VLP were counted and then a minimum of 20 fields were randomly examined.

\section{Chemical variables}

Samples for dissolved organic carbon (DOC) measurements were filtered through $0.2 \mu \mathrm{m}$ polycarbonate filters (Whatman) washed with $1.2 \mathrm{M} \mathrm{HCl}$ before use. DOC concentrations were determined using a total organic carbon analyzer (TOC-5000A; Shimadzu).

To determine chlorophyll $a$ (chl. $a$ ) concentrations, $100 \mathrm{~mL}$ water samples were filtered through $0.2-\mu \mathrm{m}$ polycarbonate filters (Whatman) and analyzed using the $N^{\prime}$ $N$-dimethylformamide method (Moran and Porath 1980) with a fluorescence spectrometer (RF-5300PC; Shimadzu).

\section{Quinone analysis}

For RQ analysis, bacteria-sized particles in 5-L of the water samples were collected using 0.2 $\mu \mathrm{m}$ pore-size Teflon filters (Advantec) after passing through $2.0 \mu \mathrm{m}$ nominal pore-sized GMF-2UM glass fiber filters (Whatman) to remove large particles such as phytoplankton and zooplankton. About $97.2-99.9 \%$ of bacterial cells passed through the GMF2UM filter (Takasu et al. 2013). In the experiment in June 2011, the GMF-2UM glass fiber filter was not used.

The RQ concentrations were determined using a modified method previously described by $\mathrm{Hu}$ et al. (1999). Briefly, quinones were extracted from the filters with a chloroform-methanol mixture $(2: 1, \mathrm{v} / \mathrm{v})$ and re-extracted into hexane. UQs and MKs contained in the crude extract were separated and purified using Sep-Pak ${ }^{\circledR}$ Plus Silica (Waters). The molecular species and concentrations of quinones were determined using a high performance liquid chromatography (HPLC) system equipped with an ODS column (pore size, 
$3.5 \mu \mathrm{m}$; Eclipse Plus C18, $3.0 \times 150 \mathrm{~mm}$; Agilent) and a photodiode array detector (SPD-M20A; Shimadzu). Details on the analytical conditions have been described by Takasu et al. (2013). The type of quinones was identified according to the UV spectrum of each peak observed in the photodiode array detector. The quinone species were identified by the linear relationship between the logarithm of the retention times of quinones and the number of their isoprene units, using the identification-supporting sheet (made by T. Kunihiro) based on the equivalent number of isoprene units (ENIU) of quinone components as described by Tamaoka et al. (1983).

In the present study, we express each RQ type as follows: ubiquinone, UQ- $n$; menaquinone, MK- $n$. The number $(n)$ indicates the number of isoprene units in the side chain of the quinone. For example, UQ-10 represents a ubiquinone with 10 isoprenoid units, and MK-9 $\left(\mathrm{H}_{8}\right)$ represents a menaquinone with 9 isoprenoid units where one of the nine units is hydrogenated with eight hydrogen atoms.

\section{Calculations}

The synthesis and destruction rates of each RQ are proxies of the growth and mortality of bacterial groups with different types of RQ. Thus, the apparent growth rates $\left(\mu_{\text {app }}, \mathrm{d}^{-1}\right)$ of bacterial subgroups with different types of RQ were calculated from the concentrations of each RQ at the beginning and end of the incubation experiment, with the assumption that bacterial growth would follow an exponential model (Landry and Hassett 1982)

$$
\mu_{\mathrm{app}}=(1 / t) \ln \left(N_{\mathrm{t}} / N_{0}\right)
$$

where $t$ is the duration of the incubation (days), and $N_{0}$ and $N_{\mathrm{t}}$ are RQ concentrations (pmol $\mathrm{L}^{-1}$ ) at the beginning and end of the incubation, respectively. Two dilution series were prepared: a $30 \mathrm{kDa}$ dilution series to estimate the combined effects of protistan grazing and viral lysis rate $\left(M_{\mathrm{g}+\mathrm{v}}, \mathrm{d}^{-1}\right)$ and a $0.2 \mu \mathrm{m}$ dilution series to determine the protistan grazing rate $\left(M_{\mathrm{g}}, \mathrm{d}^{-1}\right)$ on bacteria. The slope of the regression lines from the $0.2 \mu \mathrm{m}$ dilution series represents the grazing rate. The difference between the slopes of the regression lines 
represents the bacterial mortality rate due to viral lysis $\left(M_{\mathrm{v}}, \mathrm{d}^{-1}\right)$, and this difference was tested using analysis of covariance (ANCOVA). The intercept of the $30 \mathrm{kDa}$ dilution series gives the instantaneous growth rate $\left(\mu, \mathrm{d}^{-1}\right)$ of bacteria when neither grazing nor viral lysis occurs (Evans et al. 2003).

Carbon fluxes through bacterial subgroups with different RQ types were determined by combining the carbon conversion factor from RQ (Takasu et al. 2013) and data from the dilution experiments. For each specific bacterial subgroup, the carbon production $(C P, \mu \mathrm{g} \mathrm{C}$

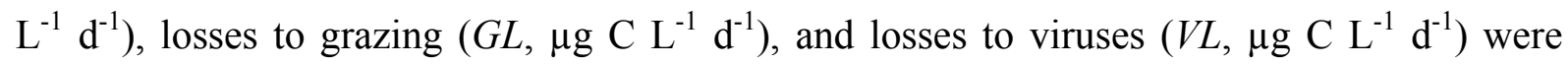
calculated using the formulas of Baudoux et al. (2008):

$$
\begin{aligned}
& C P=\mu \times P_{\mathrm{m}} \\
& G L=M_{\mathrm{g}} \times P_{\mathrm{m}} \\
& V L=M_{\mathrm{v}} \times P_{\mathrm{m}} \\
& P_{\mathrm{m}}=P_{0} \times\left[\mathrm{e}^{(\mu-M \mathrm{~g}+\mathrm{v}) t}-1\right] /\left(\mu-M_{\mathrm{g}+\mathrm{v}}\right) t
\end{aligned}
$$

where $\mu\left(\mathrm{d}^{-1}\right)$ is the dilution-based specific growth (y-intercept of the $30 \mathrm{kDa}$ regression), $M_{\mathrm{g}}$ and $M_{\mathrm{v}}$ are the dilution-based grazing and viral lysis rates (in $\mathrm{d}^{-1}$ ), respectively, $P_{0}$ (in $\mu \mathrm{g} \mathrm{C}$ $\left.\mathrm{L}^{-1}\right)$ is the initial carbon biomass of bacteria, $P_{\mathrm{m}}\left(\right.$ in $\left.\mu \mathrm{g} \mathrm{C} \mathrm{L}^{-1}\right)$ is the geometric mean carbon biomass of bacteria during the incubation, and $t$ (in d) is the time of incubation.

\section{Statistical analysis}

Analyses with Student's t-test and ANCOVA were conducted using the free statistical environment R (R Development Core Team 2011).

\section{Results}

Physicochemical and biological conditions of the sampling site

Water samples used for the modified dilution technique, covered wide ranges of physicochemical properties: water temperatures ranged from 16.0 to $27.1^{\circ} \mathrm{C}$; DOC concentrations from 1.21 to $1.56 \mathrm{mg} \mathrm{C} \mathrm{L}^{-1}$; and chl. a concentrations from 3.09 to $31.4 \mu \mathrm{g} \mathrm{L}^{-1}$ 
(Table 1). The HNF number $\left(0.5 \times 10^{6}\right.$ to $2.7 \times 10^{6}$ cells $\left.\mathrm{L}^{-1}\right)$ was in most cases higher than the PNF number $\left(0.3 \times 10^{6}\right.$ to $0.6 \times 10^{6}$ cells $\left.\mathrm{L}^{-1}\right)$. The bacteria:Total nanoflagellates $(\mathrm{TNF})$ abundance ratios in Lake Biwa ranged between 725 and 2,417 (Table 1). The VLP number varied from $2.4 \times 10^{10}$ to $4.1 \times 10^{10} \mathrm{VLP} \mathrm{L}^{-1}$ (Table 1 ). The range of viruses to bacteria abundance ratios (range: 12.3 to 36.2) falls within the average reported for freshwater systems (Maranger and Bird 1995).

\section{Estimation of growth and mortality rates}

The RQ concentrations at a dilution level of 1.0 varied in the range of 32.4 to $90.9 \mathrm{pmol} \mathrm{L}^{-1}$ at the beginning of the dilution experiments (Fig. 1A). A total of 12 types of RQ were detected, and UQ-8, UQ-10, MK-8, MK-9, and MK-9 $\left(\mathrm{H}_{8}\right)$ were detected as major RQs (Fig. 1B). In general, negative relationships between the dilution factor and apparent growth rate (RQ synthesis rate) were found in the $<0.2 \mu \mathrm{m}$ diluent (Table 2, Fig. S1). We regarded relationships with $r^{2}>0.8$ and significance levels of $p<0.1$ as statistically significant. We discussed growth and mortality rates using only the statistically significant data based on the criteria, though previous studies have used not only significant but insignificant growth and mortality values (e.g. Tijdens et al. 2008). Out of the 39 cases, 23 and 14 met these criteria for significance using the $<0.2 \mu \mathrm{m}$ diluents and the $<30 \mathrm{kDa}$ diluents, respectively (Table 2). In 5 out of the 39 experiments, both the $<0.2 \mu \mathrm{m}$ and $<30 \mathrm{kDa}$ dilution series were statistically significant, and the differences in the slopes of the two dilution series were also statistically significant (Table 2). Estimates of the growth and mortality due to grazing and lysis of UQ-8-containing bacteria in June 2011; total bacterial community (expressed as RQ in Table 2), UQ-, and UQ-8-containing bacteria in October 2011; and UQ-containing bacteria in May 2012 were statistically significant. However, most of the linear relationships between growth and the dilution factor were statistically insignificant (Table 2, Fig. S1). Rates could not be determined for UQ-10- and MK-containing bacteria in some experiments using the $<30 \mathrm{kDa}$ diluents because of the positive relationship (against theory) between the dilution factor and 
apparent growth rate (Table 2, Fig. S1).

The growth rate of the total bacterial community (expressed as RQ in Table 3) varied from 1.05 to $2.42 \mathrm{~d}^{-1}$ (Table 3), and the grazing and lysis rates of total bacteria varied from 0.46 to $0.74 \mathrm{~d}^{-1}$ and $0.69 \mathrm{~d}^{-1}$, respectively (Table 3). Growth and grazing rates varied among individual bacterial groups, and those of UQ-containing bacteria tended to be higher than those of MK-containing bacteria (Table 3). The sums of the grazing and lysis rates of individual groups had values close to their growth rates.

The changing patterns in the mortality due to grazing and lysis $\left(M_{\mathrm{g}+\mathrm{v}}\right)$ of total bacteria and UQ-8- and UQ-10-containing bacteria were similar to the growth rates of those bacteria, even though grazing rates $\left(M_{\mathrm{g}}\right)$ on those bacteria were constant (Fig. 2).

\section{Bacterial carbon production and losses}

Daily carbon production $(C P)$ in the present study ranged between 16.3 and $52.5 \mu \mathrm{g} \mathrm{C} \mathrm{L}^{-1} \mathrm{~d}^{-1}$ (average: $37.4 \mu \mathrm{g} \mathrm{C} \mathrm{L}^{-1} \mathrm{~d}^{-1}$ ) (Table 4), close to the estimates from previous studies in Lake Biwa using tritiated thymidine uptake (5 to $59 \mu \mathrm{g} \mathrm{C} \mathrm{L}^{-1} \mathrm{~d}^{-1}$ ) (Nagata 1987) and the frequency

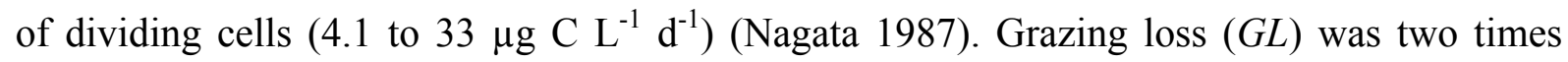
higher (average: $18.5 \mu \mathrm{g} \mathrm{C} \mathrm{L}^{-1} \mathrm{~d}^{-1}$ ) than lysis loss $(V L)$ (average: $9.2 \mu \mathrm{g} \mathrm{C} \mathrm{L}^{-1} \mathrm{~d}^{-1}$ ) (Table 4). GL showed a pattern of change similar to that of initial carbon biomass (Fig. 3). Contributions of grazing loss and lysis loss to bacterial production in Lake Biwa fell into the ranges of previous estimates in other lakes (Table 5). Total losses $(T L)$ of bacteria were almost the same (average: $36.2 \mu \mathrm{g} \mathrm{C} \mathrm{L}^{-1} \mathrm{~d}^{-1}$ ) as $C P$, and this tendency was found in individual bacterial groups (Table 4). The net carbon production of bacteria $\left(C P_{\text {net }} C P-T L\right)$ was calculated to estimate the remaining bacterial carbon biomass (Table 4). Estimates of total bacterial $C P_{\text {net }}$ were positive on average (average: $\left.1.2 \pm 4.4 \mu \mathrm{g} \mathrm{C} \mathrm{L}^{-1} \mathrm{~d}^{-1}\right)$, varying from negative $\left(-3.1 \mu \mathrm{g} \mathrm{C} \mathrm{L^{-1 }}\right.$ $\left.\mathrm{d}^{-1}\right)$ to positive $\left(5.8 \mu \mathrm{g} \mathrm{C} \mathrm{\textrm {L } ^ { - 1 }} \mathrm{d}^{-1}\right)$ values. Positive estimates of $C P_{\text {net }}$ were mostly found in UQ-8-containing bacteria (average: $0.8 \mu \mathrm{g} \mathrm{C} \mathrm{L}^{-1} \mathrm{~d}^{-1}$, range: 0.21 to $1.78 \mu \mathrm{g} \mathrm{C} \mathrm{L}^{-1} \mathrm{~d}^{-1}$ ) (Table 4). Overall, the $C P_{\text {net }}$ values of total bacteria and individual bacterial groups were less than 
$10 \%$ of each $C P$ value.

\section{Discussion}

\section{Grazing and lysis mortality of bacteria}

The dilution technique is based on a critical assumption, which assumes that the plankton mortality rates resulting from predation are proportional to the dilution effect on predator (grazer and/or virus) densities (Landry \& Hassett 1982). This assumption may not always meet because non-linear relationships between the dilution factor and apparent growth rate have been frequently reported in previous studies (e.g. Tijdens et al. 2008, Personnic et al. 2009). In the present study, the positive relationship between the dilution factor and apparent growth rate was found from some experiments using the $<30 \mathrm{kDa}$ diluent (Table 2, Fig. S1). It is known that viral lysis of bacterial cells leads to the recycling of carbon and nutrients, both of which are derived from lysed bacterial biomass and are re-supplied to bacteria (Bratbak et al. 1990; Gobler et al. 1997; Proctor and Fuhrman 1991). Thus, the possible interpretation could be that growth of bacteria was stimulated by the lysed bacterial cells in some of the $<30$ $\mathrm{kDa}$ diluent series.

In limnetic and oceanic systems, concentrations of organic substrates and inorganic nutrients are generally low, causing death of planktonic bacteria to starvation (Amy and Morita 1983). So, planktonic bacteria are required to have some physiological adaptation for efficient uptake and utilization of substrates as well as for long-term survival under carbon and energy limitation (del Giorgio and Gasol 2008). In Lake Biwa, however, the sum of total bacterial mortalities due to protistan grazing and viral lysis accounted for $96.6 \%$ (range; 89.0 $107.2 \%$ ) of daily total bacterial production in the present study. Thus, almost all bacterial production is efficiently consumed by protists and viruses before bacterial death due to other environmental factors in Lake Biwa within a day. In other words, fate of bacterial production in the epilimnion of Lake Biwa may be mainly determined through microbial interactions. 
This is the first study which demonstrates a balanced relationship between bacterial production and losses in a freshwater lake using the direct estimation method. The modified dilution method was rarely applied to the estimation of protistan grazing and virus lysis of freshwater bacteria, and only two previous studies are so far available in freshwater systems (Personnic et al. 2009, Tijdens et al. 2008) (Table 5). In those studies, however, estimates of grazing losses frequently exceeded the sum of grazing plus lysis loss estimates. Personnic et al. (2009) suggested that some complex interactions among microbes such as synergistic and antagonistic effects of viral lysis and protistan grazing on bacterial production occurred in their incubation experiments. By contrast, the sum of the grazing and lysis losses of bacteria (TL) was almost equal to $C P$ in the present study (Table 4). Thus, complex interactions among microbes might be negligible in our experiments, and almost all bacterial production is efficiently consumed by protists and viruses in Lake Biwa.

Bacterial abundances in the epilimnion of Lake Biwa were relatively constant and changed within the order of $10^{9}$ cells L ${ }^{-1}$ (Nagata 1987; Nakano 1992; Nishimura et al. 2005; Takasu et al. 2013), whereas other microbes such as picophytoplankton, nanoflagellates, and viruses respectively showed large variations from $10^{5}$ to $10^{8}$ cells $\mathrm{L}^{-1}$ (Nagata 1988), from $10^{2}$ to $10^{5}$ cells $\mathrm{L}^{-1}$ (Nagata 1988), and from $10^{9}$ to $10^{11} \mathrm{VLP} \mathrm{L}^{-1}$ (Nishimura and Nagata 2007; Pradeep Ram et al. 2010). In addition, bacterial abundance is generally less variable than bacterial production (Nagata 1987; Nakano 1992). In the present study, the percentages of remaining bacterial carbon production $\left(\% C P_{\text {net }}=\left(C P_{\text {net }} / C P\right) \times 100\right)$ ranged from -7.2 to $11.0 \%$ (average $\pm \mathrm{SD}, 3.4 \pm 9.4$ ). These estimates suggest that the less than $11 \%$ of daily bacterial production remains or excessively loses, and those small increase or decrease in net bacterial production does not change the whole bacterial abundance so much. This may be the major reason why the bacterial abundance in the epilimnion of Lake Biwa is relatively constant.

Owing to food limitation, nanoflagellates in lakes show clearance rates independent of 
bacterial density (Bird and Kalff 1993). The bacteria:TNF ratios in Lake Biwa were low (average: 1346, Table 1) and similar to those of oligotrophic lakes and oceans (Sanders et al. 1992). Thus, nanoflagellates in Lake Biwa are also under food limitation. When we calculated the specific grazing loss ( $\mathrm{SGL}=G L /$ initial TNF density), SGL estimates were relatively constant $\left(1.24 \pm 0.29 \times 10^{-5} \mu \mathrm{g} \mathrm{C}\right.$ TNF cell $\left.^{-1} \mathrm{~d}^{-1}\right)$ despite variations in the bacteria:TNF ratio (Table 1). The previous study suggested that nanoflagellates are clearing as much water as is physically possible independent of bacterial density when they are under food limitation (Bird and Kalff 1993). The results of the present study also indicate that individual TNF in Lake Biwa ingest as much bacteria as possible due to the chronically food limitation. The elimination mechanisms of bacteria should be different between protistan grazing and viral lysis, though bacterial production and the sum of grazing and lysis losses were almost equal in Lake Biwa (Table 4). In the present study, most of the viral lysis rates $\left(M_{\mathrm{v}}\right)$ were not statistically significant (Table 2), similar to those in previous studies (e.g. Tijdens et al. 2008; Personic et al. 2009). The sum of grazing and lysis mortality rates $\left(M_{\mathrm{g}+\mathrm{v}}\right)$ seasonally changed, though grazing rates $\left(M_{\mathrm{g}}\right)$ were relatively constant during the study period (Fig. 2). Thus, the changing pattern of $M_{\mathrm{g}+\mathrm{v}}$ is due to that of $M_{\mathrm{v}}$. So, the changing pattern of $M_{\mathrm{g}+\mathrm{v}}$ was similar to that of growth rate, suggesting that viral mortality is coupled with bacterial growth rate (Fig. 2). Similar results have been reported in previous studies (e.g., Weinbauer 2003). In Lake Biwa, the loss processes of bacterial production can be explained by a combination of protistan grazing pressure, which is independent of bacterial abundance, and viral lysis, which is dependent on bacterial growth (Fig. 2, RQ).

Carbon fluxes through major bacterial groups and differentiating the ecological traits of bacterial groups

The present study elucidated that planktonic bacterial assemblages in Lake Biwa consisted of various RQs subgroups with different growth and mortality rates (Table 3). The growth rates of UQ-containing bacteria were higher than those of MK-containing bacteria in Lake Biwa 
(Table 3). Because of the large midpoint potential of UQs, UQs are thermodynamically favorable compounds to use oxygen as an electron acceptor compared to MKs, and this makes energy gains by UQs higher than those of MKs (Søballe and Pool 1999). The coupling between bacterial production and oxygen consumption (respiration) has been reported in aquatic systems (reviewed by del Girogio and Cole 1998; Robinson 2008). Thus, UQ-containing bacteria may have an advantage over other bacteria in the epilimnion of Lake Biwa because of the lake's oxygenated condition. UQ-containing bacteria showed higher GL than MK-containing bacteria (Table 3), probably due to higher abundance which would have higher encounter with nanoflagellates. In addition, there may be another reason why UQ-containing bacteria had higher GL. In freshwater planktonic bacterial community, UQ-8and UQ-10-containing bacteria are generally gram-negative Proteobacteria, whereas MK-8, MK-9, and MK-9 $\left(\mathrm{H}_{8}\right)$-containing bacteria are gram-positive Actinobacteria (e.g. Hiraishi and Kato 1999). The consumption of gram-positive freshwater planktonic bacteria (mainly Actinobacteria) is selectively avoided by nanoflagellates due to various protection mechanisms of gram-positive bacteria such as cell surface charge and cell size reduction (reviewed by Pernthaler 2005). Thus, it is possible that UQ-containing bacteria are preferentially grazed by nanoflagellates.

UQ-8- and UQ-10-containing bacteria were the most dominant and fastest-growing bacterial groups during the study period (Fig. 1, Table 3). The average CPS of UQ-8- and UQ-10-containing bacteria were respectively estimated at 12.2 and $13.8 \mu \mathrm{g} \mathrm{C} \mathrm{L}^{-1} \mathrm{~d}^{-1}$, accounting for $31.7 \%$ (range: 28.4 to $35.2 \%$ ) and $28.5 \%$ (range: 25.0 to $32.1 \%$ ) of total bacterial $C P$ (Table 4). The sum of the average $T L$ of UQ-8- and UQ-10-containing bacteria (26.0 $\mu \mathrm{g} \mathrm{C} \mathrm{L}^{-1} \mathrm{~d}^{-1}$ ) also accounted for $60 \%$ of total bacterial $T L$ (Table 4). Hence, the fate of those two bacterial groups explained a large portion of the carbon fluxes within the microbial loop of Lake Biwa. Our estimation thus implies that the magnitude of carbon fluxes within the microbial loop can be regulated by the production of major bacterial groups. 
R-BT065 cluster bacteria (a subcluster of Beta-proteobacteria) have been reported to be the most abundant (up to $50 \%$ of total bacteria) (Zwart et al. 2002; 2003) and have UQ-8 as their major RQ (e.g., Hahn et al. 2010a; 2010b; Kasalický et al. 2010). R-BT065 cluster bacteria have been reported to be the fastest-growing segment of bacterial communities in European freshwater lakes (Šimek et al. 2006; Salcher et al. 2008). These bacteria preferentially inhabit the oxygenated layer of oligo-mesotrophic lakes (Piburger See, Austria; Lake Zurich, Switzerland) (Salcher et al. 2008; 2011). The environmental conditions of the epilimnetic water in the north basin of Lake Biwa may be similar to those of the aforementioned European lakes (Nishimura et al. 2005; Kim et al. 2006; Takasu et al. 2013). UQ-10-containing bacteria have been classified as Alpha-proteobacteria (Hiraishi 1999). In the freshwater Alpha-proteobacteria, members of the LD12 clade are one of the most abundant ubiquitous lineages (Salcher et al. 2011). Previous study suggested that LD12 bacteria generally prefer the upper epilimnetic water layers during nutrient limited summer season (Salcher et al. 2011). This feature is well consistent with UQ-10-containing bacteria in Lake Biwa (Takasu et al. 2013).

The $C P_{\text {net }}$ of UQ-8-containing bacteria showed positive estimates, whereas the $C P_{\text {net }}$ of UQ-10 containing bacteria showed negative estimates in the present study (Table 4). In our previous study, UQ-8-containing bacteria dominated in Lake Biwa throughout a year, whereas biomass of UQ-10-containing bacteria was relatively low (Takasu et al. 2013). In addition, biomass of those bacterial groups showed different seasonal changing patterns (Takasu et al. 2013). Thus, it is likely that relatively low biomass of UQ-10-containing bacteria was due to higher loss of the bacteria by protistan grazing and/or viral lysis than that of UQ-8-containing bacteria in Lake Biwa.

\section{Conclusion}

Our study is the first to demonstrate a balanced relationship between bacterial production and losses in a freshwater lake using the modified dilution method. UQ-8- and UQ-10-containing 
404 bacteria were the two dominant groups, and the sum of their production and losses explained

$40560 \%$ of the carbon fluxes within the microbial loop. Thus, a large portion of carbon fluxes 406 through the bacterial community may be explained by the carbon fluxes of dominant bacterial 407 groups.

408

\section{Acknowledgments}

We are grateful to Dr. Masayuki Ushio for his invaluable comments as well as his

411 encouragement throughout this study. We also thank Mr. Tadatoshi Koitabashi and Dr.

412 Yukiko Goda for their assistance during field sampling, and thank other colleagues at the

413 Center for Ecological Research, Kyoto University, for their valuable comments on this study.

414 This study was partly supported by Japan Society for the Promotion of Science (JSPS)

415 KAKENHI Grant Numbers 23370010 and Japan Science and Technology Strategic

416 International Research Cooperative Program (Japan-China) on Science and Technology for

417 Environmental Conservation and Construction of a Society with Less Environmental Burden

418 "Fate of dissolved organic matter in lakes with special reference to loading and pollution" to

419 S.N. and 21710081,23710010 to T.K. H.T. was supported by JSPS KAKENHI Grant

$420 \quad$ Number 11J00658. 


\section{References}

424

Amy PS, Morita RY (1983) Starvation-survival patterns of sixteen freshly isolated open-ocean bacteria. Appl Environ Microbiol 45:1109-1115

Azam F, Fenchel T, Field JG, Gray JS, Meyer-Reil LA, Thingstad F (1983) The ecological role of water-column microbes in the sea. Mar Ecol Prog Ser 10:257-263

Baudoux AC, Veldhuis MJW, Noordeloos AAM, van Noort G, Brussaard CPD (2008) Estimates of virus- vs. grazing induced mortality of picophytoplankton in the North Sea during summer. Aquat Microb Ecol 52:69-82

Bettarel Y, Amblard C, Sime-Ngando T, Carrias J-F, Sargos D, Garabétian F, Lavandier P (2003) Viral lysis, flaellate grazing potential, and bacterial production in Lake Pavin. Microb Ecol 45:119-127

Bird D, Kalff J (1993) Protozoan grazing and the size-activity structure of limnetic bacterial communities. Can J Fish aquat Sci 50:370-380

Bouvier T, del Giorgio PA (2003) Factors influencing the detection of bacterial cells using fluorescence in situ hybridization (FISH): A quantitative review of published reports. FEMS Microbiol Ecol 44:3-15

Bratbak G, Heldal M, Norland S, Thingstad TF (1990) Viruses as partners in spring bloom microbial trophodynamics. Appl Environ Microbiol 56:1400-1405

Caron DA (1983) Technique for enumeration of heterotrophic and phototrophic nanoplankton, using epifluorescence microscopy, and comparison with other procedures. Appl Environ Microbiol 46: 491-498

Cole JJ, Findlay SS, Pace ML (1988) Bacterial production in fresh and saltwater ecosystems: a cross-system overview. Mar Ecol Prog Ser 43:1-10 
Collins MD, Jones D (1981) Distribution of isoprenoid quinone structural types in bacteria and their taxonomic implications. Microbiol Rev 45: 316-354

Constanza R, d'Arge R, de Groot R, Farber S, Grasso M, Hannon B, Limburg K, Naeem S, O’Neill RV, Paruelo J, Raskin RG, Sutton P, van den Belt M (1997) The value of the world's ecosystem services and natural capital. Nature 387: 253-260

del Girogio PA, Cole JJ (1998) Bacterial growth efficiency in natural aquatic systems. Ann Rev Ecol Systematics 29: 503-541

del Giorgio PA, Gasol JM (2008) Physiological structure and single-cell activity in marine bacterioplankton, In Kirchman DL (ed) Microbial ecology of the oceans. (2nd edition) Wiley, New York, pp. 243-298

Ducklow HW (2000) Bacterial production and biomass in the oceans. In Kirchman DL (ed) Microbial ecology of the oceans. Wiley, New York, pp 85-120

Evans C, Archer SD, Jacquet S, Wilson WH (2003) Direct estimates of the contribution of viral lysis and microzooplankton grazing to the decline of a Micromonas spp. population. Aquat Microb Ecol 30:207-219

Glöckner FO, Fuchs BM, Amann R (1999) Bacterioplankton compositions of lakes and oceans: a first comparison based on fluorescence in situ hybridization. Appl Environ Microbiol 65:3721-3726

Gobler CJ, Hutchins DA, Fisher NS, Cosper EM, Sanudo-Wilhelmy SA (1997) Release and bioavailability of $\mathrm{C}, \mathrm{N}, \mathrm{P}, \mathrm{Se}$, and Fe following viral lysis of a marine chrysophyte. Limnol Oceanogr 42:1492-1504

Gobler CJ, Davis TW, Deonarine SN, Saxton MA, Lavrentyev PJ, Jochem FJ, Wilhelm SW. (2008) Grazing and virus-induced mortality of microbial populations before and during the onset of annual hypoxia in Lake Erie. Aquat Microb Ecol 51: 117- 
470

471

472

473

474

128

Hahn MW, Kasalický V, Jezbera J, Brandt U, Jezberová J, Šimek K (2010a) Limnohabitans curvus gen. nov., sp. nov., a planktonic bacterium isolated from a freshwater lake. Int J Syst Evol Microbiol 60:1358-1365

Hahn MW, Kasalický V, Jezbera J, Brandt U, Šimek K (2010b) Limnohabitans australis sp. nov., isolated from a freshwater pond, and emended description of the genus Limnohabitans. Int J Syst Evol Microbiol 60:2946-2950

Hedrick DB, White DC (1986) Microbial respiratory quinones in the environment. J Microbiol Meth 5:243-254

Ducklow HW (2000) Bacterial production and biomass in the oceans. In Kirchman DL (ed) Microbial ecology of the oceans. Wiley, New York, pp 85-120

Herdendorf CE (1990) Distribution of the world's large lakes. In Tilzer MM, Serruya C (ed) Large lakes: ecological structure and function. Springer Verlag, Berlin. pp. 338

Hiraishi A (1999) Isoprenoid quinones as biomarkers of microbial populations in the environment. J Biosci Bioeng 88:449-460

Hiraishi A, Kato K (1999) Quinone profiles in lake sediments: Implications for microbial diversity and community structures. J Gen Appl Microbiol 45: 221-227

Hu H-Y, Fujie K, Urano K (1999) Development of a novel solid phase extraction method for the analysis of bacterial quinones in activated sludge with a higher reliability. J. Biosci. Bioeng. 87: 378-382

Jacquet S, Domaizon I, Personnic S, Pradeep Ram AS, Hedal M, Duhamel S, Sime-Ngando T (2005) Estimates of protozoan- and viral-mediated mortality of bacterioplankton in Lake Bourget (France). Freshw Biol 50:627-645 
494

495

496

497

Kasalický V, Jezbera J, Šimek K, Hahn MW (2010) Limnohabitans planktonicus sp. nov. and Limnohabitans parvus sp. nov., planktonic betaproteobacteria isolated from a freshwater reservoir, and emended description of the genus Limnohabitans. Int J Syst Evol Microbiol 60:2710-2714

Kim C, Nishimura Y, Nagata T (2006) Role of dissolved organic matter in hypolimnetic mineralization of carbon and nitrogen in a large, monomictic lake. Limnol Oceanogr $51: 70-78$

Kunihiro T, Takasu H, Miyazaki T, Uramoto Y, Kinoshita K, Yodnarasri S, Hama D, Wada M, Kogure K, Ohwada K, Tsutsumi H (2011) Increase in Alphaproteobacteria in association with a polychaete, Capitella sp. I, in the organically enriched sediment. The ISME J 5:1818-1831

Landry MR, Hassett RP (1982) Estimating the grazing impact of marine micro-zooplankton. Mar Biol 67:283-288

Landry MR, Haas LW, Fagerness VL (1984) Dynamics of microbial plankton communities: experiments in Kaneohe Bay, Hawaii. Mar Ecol Prog Ser 16:127-133

Maranger R, Bird DF (1995) Viral abundance in aquatic systems: a comparisonbetween marine and fresh waters. Mar Ecol Prog Ser 121:217-226

Miki T, Yokokawa T, Nagata T, Yamamura N (2008) Immigration of prokaryotes to local environments enhances remineralization efficiency of sinking particles: a metacommunity model. Mar Ecol Prog Ser 366:1-14

Moran R, Porath D (1980) Chlorophyll determination in intact tissues using $N, N$-Dimethylformamide. Plant Physiol 65:478-479

Nagata T (1987) Production rate of planktonic bacteria in the north basin of Lake Biwa, Japan. Appl Environ Microbiol 53:2872-2882 
Nagata T (1988) The microflagellate-picoplankton food linkage in the water column of Lake Biwa. Limnol Oceanogr 33:504-517

Nagata T (1990) Contribution of picoplankton to the grazer food chain of Lake Biwa. In Tilzer MM, Serruya C (ed) Large lakes: ecological structure and function. Springer Verlag, Berlin. pp. 526-539

Nagata T, Kumagai M, Yoshiyama K (2012) Ondanka no kosho-gaku. Kyoto University press (in Japanese)

Nakano S-I (1992) Changes in bacterioplankton production and dominant algal species in the north basin of Lake Biwa. Jpn J Limnol 53:145-149

Nishimura Y, Kim C, Nagata $\mathrm{T}$ (2005) Vertical and Seasonal Variations of Bacterioplankton subgroups with different nucleic acid contents: possible regulation by phosphorus. Appl Microbiol 71:5828-5836

Nishimura Y, Nagata T (2007) Alphaproteobacterial dominance in a large mesotrophic lake (Lake Biwa, Japan). Aquat Microb Ecol 48:231-240

Noble RT, Fuhrman JA (1998) Use of SYBR Green I for rapid epifluorescence counts of marine viruses and bacteria. Aquat Microb Ecol 14:113-118

Patel A, Nobel RT, Steele JA, Schwalbach MS, Hewson I, Fuhrman JA (2008) Virus and prokaryote enumeration from planktonic aquatic environments by epifluorescence microscopy with SYBR Green I. Nat Protoc 2:269-276

Pernthaler J, Glöckner FO, Unterholzner S, Alfreider A, Psenner R, Amann R (1998) Seasonal community and population dynamics of pelagic Bacteria and Archaea in a high mountain lake. Appl Environ Microbiol 64:4299-4306

Pernthaler J (2005) Predation on prokaryotes in the water column and its ecological implications. Nature Rev Microbiol 3:537-546 
Personnic S, Domaizon I., Sime-Ngando T, Jacquet S (2009) Seasonal variations of microbial abundances and virus- versus flagellate-induced mortality of picoplankton in three peri-alphine lakes. J Plankton Res 31: 1161-1177

Pirlot S, Unrein F, Descy JP, Servais P (2007) Fate of heterotrophic bacteria in Lake Tanganyika (East Africa). FEMS Microbial Ecol 62:354-364

Porter KG, Feig YS (1980) The use of DAPI for identifying and counting aquatic microflora. Limnol Oceanogr 25:943-948

Pradeep Ram AS, Nishimura Y, Tomaru Y, Nagasaki K, Nagata T (2010) Seasonal variation in viral-induced mortalityof bacterioplankton in the water column of a large mesotrophic lake (Lake Biwa, Japan). Aquat Microb Ecol 58: 249-259

Proctor LM, Fuhrman JA (1991) Roles of viral infection in organic particulate flux. Mar Ecol Prog Ser 69:133-142

R Development Core Team (2011) R: A language and environment for statistical computing. Vienna, Austria

Robinson C (2008) Heterotrophic bacterial respiration. In Kirchman DL (ed) Microbial ecology of the oceans. Wiley, New York, pp 299-334

Salcher MM, Pernthaler J, Zeder M, Psenner R, Posch T (2008) Spatio-temporal niche separation of planktonic Betaproteobacteria in an oligo-mesotrophic lake. Environ Microbiol 10:2074-2086

Salcher MM, Pernthaler J, Posch T (2011) Seasonal bloom dynamics and ecophysiology of the freshwater sister clade of SAR11 bacteria 'that rule the waves' (LD12). The ISME J 5:1242-1252

Salcher MM, Pernthaler J, Frater N, Posch T (2011) Vertical and longitudinal distribution patterns of different bacterioplankton populations in a canyon-shaped, 
Sanders RW, Caron DA, Berninger U-G (1992) Relationships between bacteria and heterotrophic nanoplankton in marine and fresh waters: an inter-ecosystem comparison. Mar Ecol Prog Ser 86:1-14

570

Šimek K, Pernthaler J, Weinbauer MG, Horňák K, Dolan JR, Nedoma J, Mašín M, Amann R (2001) Changes in bacterial community composition and dynamics and viral mortality rates associated with enhanced flagellate grazing in a mesotrophic reservoir. Appl Environ Microbiol 67: 2723-2733

Šimek K, Horňák K, Jezbera J, Nedoma J, Vrba J, Straškrábová V, Macek N, Dolan JR, Hahn MW (2006) Maximum growth rates and possible life strategies of different bacterioplankton groups in relation to phosphorus availability in a freshwater reservoir. Environ Microbiol 8:1613-1624

Šimek K, Weinbauer G, Horňák K, Jezbera J, Nedoma J, Dolan JR (2007) Grazer and virus-induced mortality of bacterioplankton accelerates development of Flectobacillus populations in a freshwater community. Environ Microbiol 9: 789800

Søballe B, Pool KP (1999) Microbial ubiquinones: multiple roles in respiration, gene regulation and oxidative stress management. Microbiology 145: 1817-1830

Taira Y, Uchimiya M, Kudo I (2009) Simultaneous estimation of viral lysis and protozoan grazing on bacterial mortality using a modified virus-dilution method. Mar Ecol Prog Ser 379: 23-32

Takasu H, Kunihiro T, Nakano S-I (2013) Estimation of carbon biomss and community structure of planktonic bacteria in Lake Biwa using respiratory quinone analysis. Limnology 14: 247-256 
Tamaoka J, Katayama-Fujimura H, Kuraishi H (1983) Analysis of bacterial menaquinone mixtures by high performance liquid chromatography. J Appl Microbiol 54: 31-36

Thingstad TF (2000) Elements of a theory for the mechanisms controlling abundance, diversity, and biogeochemical role of lytic bacterial viruses in aquatic systems. Limnol Oceanogr 45:1320-1328

Tijdens M, Van de Wall BD, Slovackova H, Hoogveld HL, Gons HJ (2008) Estimates of bacterial and phytoplankton mortality caused by viral lysis and microzooplankton grazing in a shallow eutrophic lake. Freshw Biol 53:1126-1141

Tremaine SC, Mills AL (1987) Tests of the critical assumptions of the dilution method for estimating bacterivory by microeucaryotes. Appl Environ Microbiol 53:29142921

Weinbauer MG, Höfle, MG (1998) Significance of viral lysis and flagellate grazing as factors controlling bacterioplankton production in a eutrophic lake. Appl Environ Microbiol 64: 431-438

Weinbauer MG, Christaki U, Nedoma J, Šimek K. (2003) Comparing the effects of resource enrichment and grazing on viral production in a meso-eutrophic reservoir. Aquat Microb Ecol 31:137-144

Zwart G, Crump BC, Kamst-van Agterveld MP, Hagen F, Han S-K (2002) Typical freshwater bacteria: an analysis of available 16S rRNA gene sequences from plankton of lakes and rivers. Aquat Microb Ecol 28:141-155

Zwart G, van Hannen EJ, Kamst-van Agterveld MP, der Gucht KV, Lindström ES, Wichelen JV, Lauridsen T, Crump BC, Han S-K, Declerck S (2003) Rapid screening for freshwater bacterial groups by using reverse line blot hybridization. 
615 
Table 1. Physico-chemical and biological variabes

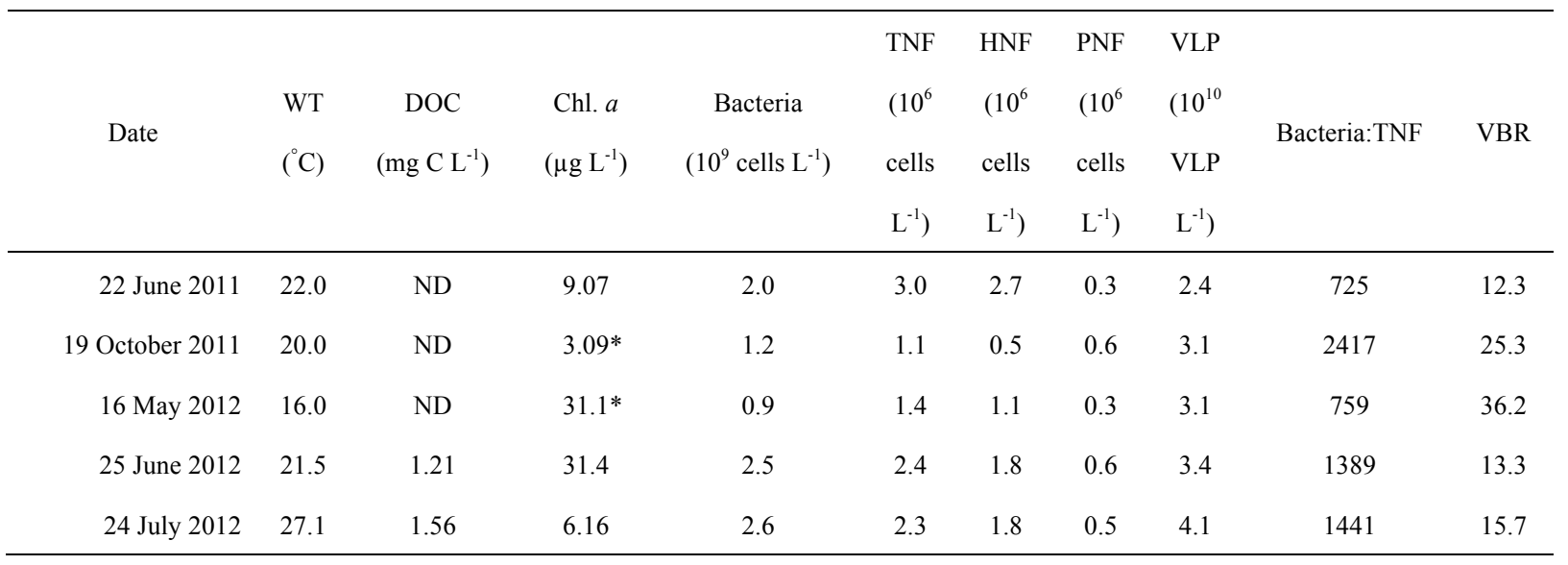

WT, Water Temperature

ND, Not Determined

VBR, Viruses to bacterium ratio

*Water samples were filtered using different type of filter (GF/F glass fiber filter, Whatman)

(I. Mukherjee and S.D. Thottathil, personal communication). 
Table 2. Summary of growth $(\mu)$, grazing mortality $\left(M_{\mathrm{g}}\right)$, lysis mortality $\left(M_{\mathrm{v}}\right)$, and total mortality $\left(M_{\mathrm{g}+\mathrm{v}}\right)$ from results of the dilution experiments.

\begin{tabular}{|c|c|c|c|c|c|c|c|c|c|c|}
\hline \multirow{2}{*}{ Date } & \multirow{2}{*}{ Bacterial RQ type } & \multirow{2}{*}{ Diluent } & \multirow{2}{*}{$\begin{array}{c}\text { Dilution } \\
\text { level }\end{array}$} & \multicolumn{2}{|c|}{ Linear fit } & \multirow{2}{*}{$\begin{array}{c}\text { Regression slopes } \\
\quad p \text { limit }\end{array}$} & \multirow{2}{*}{$\mu$} & \multirow{2}{*}{$M_{\mathrm{g}}$} & \multirow{2}{*}{$M_{\mathrm{V}}$} & \multirow{2}{*}{$M_{\mathrm{g}+\mathrm{v}}$} \\
\hline & & & & $r^{2}$ & $p$ limit & & & & & \\
\hline \multirow[t]{14}{*}{22 June 2011} & \multirow[t]{2}{*}{ RQ } & $0.2 \mu \mathrm{m}$ & 4 & 0.993 & $<0.01$ & \multirow{2}{*}{ NS } & \multirow{2}{*}{1.128} & \multirow{2}{*}{0.697} & \multirow{2}{*}{0.123} & \multirow{2}{*}{0.820} \\
\hline & & $30 \mathrm{kDa}$ & 4 & 0.659 & NS & & & & & \\
\hline & \multirow[t]{2}{*}{ UQ } & $0.2 \mu \mathrm{m}$ & 4 & 0.996 & $<0.01$ & \multirow{2}{*}{ NS } & \multirow{2}{*}{1.206} & 0777 & 0123 & 0.010 \\
\hline & & $30 \mathrm{kDa}$ & 4 & 0.727 & NS & & & 法. & 0.135 & 0.910 \\
\hline & MK & $0.2 \mu \mathrm{m}$ & 4 & 0.688 & NS & NS & 0714 & 042 & $=0082$ & 0338 \\
\hline & & $30 \mathrm{kDa}$ & 4 & 0.175 & NS & 100 & 0.119 & 0.72 & .002 & 0.500 \\
\hline & UQ-8 & $0.2 \mu \mathrm{m}$ & 4 & 0.957 & $<0.05$ & $<005$ & 1043 & 0578 & 1005 & 1673 \\
\hline & & $30 \mathrm{kDa}$ & 4 & 0.965 & $<0.05$ & $=0.03$ & 1.945 & $0.0 / 6$ & 1.095 & $1.0 / 3$ \\
\hline & UQ-10 & $0.2 \mu \mathrm{m}$ & 4 & 0.989 & $<0.01$ & NS & 0 & 0.82 & & \\
\hline & & $30 \mathrm{kDa}$ & 4 & 0.004 & NS & $\mathrm{NOS}$ & 0 & 0.012 & & \\
\hline & MK-8 & $0.2 \mu \mathrm{m}$ & 4 & 0.127 & NS & NS & 0360 & 0070 & 0178 & 0248 \\
\hline & & $30 \mathrm{kDa}$ & 4 & 0.304 & NS & NOS & 0.500 & 0.070 & 0.170 & 0.210 \\
\hline & MK-9 $\left(\mathrm{H}_{8}\right)$ & $0.2 \mu \mathrm{m}$ & $3 *$ & 0.865 & $<0.1$ & NS & 0 & -0.248 & & \\
\hline & & $30 \mathrm{kDa}$ & 4 & 0.464 & NS & No & 0 & -0.240 & & \\
\hline 19 October 2011 & RQ & $0.2 \mu \mathrm{m}$ & 4 & 0.980 & $<0.01$ & $<001$ & 1225 & 0450 & 0.90 & 1148 \\
\hline & & $30 \mathrm{kDa}$ & 4 & 0.996 & $<0.01$ & 0.01 & 1.220 & $0.4 \mathrm{Jy}$ & 0.089 & 1.140 \\
\hline & UQ & $0.2 \mu \mathrm{m}$ & 4 & 0.944 & $<0.05$ & $<0,01$ & 1767 & 0268 & 1.471 & 1733 \\
\hline & & $30 \mathrm{kDa}$ & 4 & 0.978 & $<0.05$ & 0.01 & 10101 & 0.200 & 1071 & \\
\hline & MK & $0.2 \mu \mathrm{m}$ & 4 & 0.968 & $<0.05$ & $<005$ & 0 & 0602 & & \\
\hline & & $30 \mathrm{kDa}$ & 4 & 0.436 & NS & 0.00 & 0 & 0.002 & & \\
\hline & UQ-8 & $0.2 \mu \mathrm{m}$ & 4 & 0.926 & $<0.05$ & $<001$ & 2188 & 0543 & 1554 & 2007 \\
\hline & & $30 \mathrm{kDa}$ & 4 & 0.998 & $<0.01$ & 0.01 & 2.100 & 0.070 & 1.007 & 2.031 \\
\hline & UQ-10 & $0.2 \mu \mathrm{m}$ & 4 & 0.440 & NS & NS & 0.192 & & & 0.161 \\
\hline & & $30 \mathrm{kDa}$ & 4 & 0.063 & NS & & & & & \\
\hline & MK-7 & $0.2 \mu \mathrm{m}$ & 4 & 0.986 & $<0.01$ & $<01$ & 0 & 0.968 & & \\
\hline & & $30 \mathrm{kDa}$ & 4 & 0.069 & NS & 0.1 & 0 & 0.300 & & \\
\hline & MK-8 & $0.2 \mu \mathrm{m}$ & 4 & 0.819 & $<0.1$ & $<005$ & 0 & 0533 & & \\
\hline & & $30 \mathrm{kDa}$ & 4 & 0.768 & NS & $0.0 J$ & 0 & . & & \\
\hline & MK-9 & $0.2 \mu \mathrm{m}$ & 4 & 0.873 & $<0.1$ & $<01$ & 0 & 0500 & & \\
\hline & & $30 \mathrm{kDa}$ & $3 *$ & 0.651 & NS & 0.1 & 0 & 0.007 & & \\
\hline & MK-9 $\left(\mathrm{H}_{8}\right)$ & $0.2 \mu \mathrm{m}$ & 4 & 0.882 & $<0.1$ & $<005$ & 0 & 0351 & & \\
\hline & & $30 \mathrm{kDa}$ & 4 & 0.601 & NS & 0.00 & 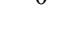 & 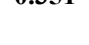 & & \\
\hline 16 May 2012 & RQ & $0.2 \mu \mathrm{m}$ & 4 & 0.612 & NS & $<005$ & 2424 & 0.646 & 1511 & 2157 \\
\hline & & $30 \mathrm{kDa}$ & 4 & 0.948 & $<0.05$ & $0.0 J$ & 2.724 & 0.070 & 1.011 & 2.101 \\
\hline & UQ & $0.2 \mu \mathrm{m}$ & 4 & 0.829 & $<0.1$ & $<0.05$ & 1.382 & 2.066 & -0.936 & 1.13 \\
\hline & & $30 \mathrm{kDa}$ & 4 & 0.999 & $<0.001$ & & & & & \\
\hline & MK & $0.2 \mu \mathrm{m}$ & 4 & 0.591 & NS & NS & 0.995 & 1136 & -0859 & 0.277 \\
\hline & & $30 \mathrm{kDa}$ & 4 & 0.427 & NS & 105 & 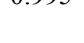 & 1.150 & 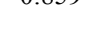 & 0.211 \\
\hline & UQ-8 & $0.2 \mu \mathrm{m}$ & 4 & 0.648 & NS & $<005$ & 2062 & 0721 & 2052 & 773 \\
\hline & & $30 \mathrm{kDa}$ & 4 & 0.952 & $<0.05$ & $0.0 J$ & 2.302 & 0.121 & 2.052 & 2.17 \\
\hline & UQ-10 & $0.2 \mu \mathrm{m}$ & 4 & 0.710 & NS & $<005$ & 2524 & 0552 & 2012 & 2564 \\
\hline & & $30 \mathrm{kDa}$ & 4 & 0.944 & $<0.05$ & $0.0 J$ & 2.027 & . & 2.012 & 年 \\
\hline & MK-8 & $0.2 \mu \mathrm{m}$ & 4 & 0.559 & NS & NS & 0.481 & 1027 & $=0718$ & 0300 \\
\hline & & $30 \mathrm{kDa}$ & 4 & 0.198 & NS & 105 & 0.701 & 1.021 & 0.110 & 0.50 \\
\hline & MK-9 $\left(\mathrm{H}_{8}\right)$ & $0.2 \mu \mathrm{m}$ & 4 & 0.098 & NS & NS & 0.253 & 0.290 & -0.188 & 0.102 \\
\hline & & $30 \mathrm{kDa}$ & $3 *$ & 0.101 & NS & & & & & \\
\hline
\end{tabular}


Table 2. Continued

\begin{tabular}{|c|c|c|c|c|c|c|c|c|c|c|}
\hline \multirow{2}{*}{ Date } & \multirow{2}{*}{ Bacterial RQ type } & \multirow{2}{*}{ Diluent } & \multirow{2}{*}{$\begin{array}{c}\text { Dilution } \\
\text { level }\end{array}$} & \multicolumn{2}{|c|}{ Linear fit } & \multirow{2}{*}{$\begin{array}{c}\text { Regression slopes } \\
p \text { limit } \\
\end{array}$} & \multirow[b]{2}{*}{$\mu$} & \multirow{2}{*}{$M_{\mathrm{g}}$} & \multirow{2}{*}{$M_{\mathrm{V}}$} & \multirow{2}{*}{$M_{\mathrm{g}+\mathrm{V}}$} \\
\hline & & & & $r^{2}$ & $p$ limit & & & & & \\
\hline \multirow[t]{16}{*}{25 June 2012} & \multirow[t]{2}{*}{ RQ } & $0.2 \mu \mathrm{m}$ & 4 & 0.968 & $<0.05$ & \multirow{2}{*}{$<0.1$} & \multirow{2}{*}{1.448} & \multirow{2}{*}{0.644} & \multirow{2}{*}{0.720} & \multirow{2}{*}{1.364} \\
\hline & & $30 \mathrm{kDa}$ & $3 * *$ & 0.958 & NS & & & & & \\
\hline & \multirow[t]{2}{*}{ UQ } & $0.2 \mu \mathrm{m}$ & 4 & 0.976 & $<0.05$ & \multirow{2}{*}{ NS } & \multirow{2}{*}{1.567} & \multirow{2}{*}{1.368} & \multirow{2}{*}{0.080} & \multirow{2}{*}{1.448} \\
\hline & & $30 \mathrm{kDa}$ & $3 * *$ & 0.954 & NS & & & & & \\
\hline & \multirow[t]{2}{*}{ MK } & $0.2 \mu \mathrm{m}$ & 4 & 0.831 & $<0.1$ & \multirow{2}{*}{$<0.05$} & \multirow{2}{*}{1.349} & \multirow{2}{*}{0.113} & 1183 & 1206 \\
\hline & & $30 \mathrm{kDa}$ & $3 * *$ & 0.963 & NS & & & & $1.10 \mathrm{~J}$ & 1.290 \\
\hline & UQ-8 & $0.2 \mu \mathrm{m}$ & 4 & 0.985 & $<0.01$ & NS & 1245 & 1580 & 0381 & 1208 \\
\hline & & $30 \mathrm{kDa}$ & 4 & 0.961 & NS & NS & $1.24 \mathrm{~J}$ & 1.007 & -0.001 & 1.200 \\
\hline & UQ-10 & $0.2 \mu \mathrm{m}$ & 4 & 0.958 & $<0.05$ & NS & 1816 & 1077 & 0522 & 1599 \\
\hline & & $30 \mathrm{kDa}$ & $3 * *$ & 0.937 & NS & $\mathrm{NOS}$ & 1.010 & $1.0 / 1$ & 0.522 & 1.09 \\
\hline & MK-8 & $0.2 \mu \mathrm{m}$ & 4 & 0.019 & NS & NS & 0 & 0009 & & \\
\hline & & $30 \mathrm{kDa}$ & $3^{* *}$ & 0.911 & NS & 105 & 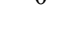 & 0.000 & & \\
\hline & MK-9 & $0.2 \mu \mathrm{m}$ & 4 & 0.595 & NS & NS & 0220 & 0388 & $=0126$ & 0262 \\
\hline & & $30 \mathrm{kDa}$ & $3 * *$ & 0.259 & NS & NS & 0.220 & 0.300 & -0.120 & 0.202 \\
\hline & MK-9(H $\left(\mathrm{H}_{8}\right)$ & $0.2 \mu \mathrm{m}$ & 4 & 0.003 & NS & NS & (24) & 0046 & 0277 & 0323 \\
\hline & & $30 \mathrm{kDa}$ & $3 * *$ & 0.983 & $<0.1$ & NS & 0.242 & 0.046 & 0.271 & 0.323 \\
\hline 24 July 2012 & RQ & $0.2 \mu \mathrm{m}$ & 4 & 0.862 & $<0.1$ & NS & 1048 & 0744 & 0379 & 1123 \\
\hline & & $30 \mathrm{kDa}$ & 4 & 0.870 & $<0.1$ & $\mathrm{NS}$ & 1.048 & $0 . / 44$ & 0.379 & 1.129 \\
\hline & UQ & $0.2 \mu \mathrm{m}$ & 4 & 0.92 & $<0.05$ & NS & 1446 & 1007 & 0497 & 1409 \\
\hline & & $30 \mathrm{kDa}$ & 4 & 0.897 & $<0.1$ & NO & 1.440 & 1.001 & 0.492 & 1045 \\
\hline & MK & $0.2 \mu \mathrm{m}$ & 4 & 0.76 & NS & NS & 0416 & 0644 & - 24 & 0.404 \\
\hline & & $30 \mathrm{kDa}$ & 4 & 0.655 & NS & 1Vi & 0.410 & 0.044 & -0.24 & 0.404 \\
\hline & UQ-8 & $0.2 \mu \mathrm{m}$ & 4 & 0.930 & $<0.05$ & NS & 1202 & 0926 & 0256 & 1182 \\
\hline & & $30 \mathrm{kDa}$ & 4 & 0.891 & $<0.1$ & INS & 1.202 & 0.920 & & \\
\hline & UQ-10 & $0.2 \mu \mathrm{m}$ & 4 & 0.911 & $<0.05$ & NS & 1.636 & 1.120 & 0.647 & 1.767 \\
\hline & & $30 \mathrm{kDa}$ & 4 & 0.913 & $<0.05$ & & & & & \\
\hline & MK-8 & $0.2 \mu \mathrm{m}$ & 4 & 0.393 & NS & NS & 0.026 & 0.392 & -0.269 & 0.123 \\
\hline & & $30 \mathrm{kDa}$ & 4 & 0.222 & NS & & & & & \\
\hline & MK-9 & $0.2 \mu \mathrm{m}$ & 4 & 0.535 & NS & NS & 1.398 & 0.409 & 0.893 & 1.302 \\
\hline & & $30 \mathrm{kDa}$ & 4 & 0.841 & $<0.1$ & $\mathrm{NOS}$ & & & & \\
\hline & MK-9 $\left(\mathrm{H}_{8}\right)$ & $0.2 \mu \mathrm{m}$ & 4 & 0.923 & $<0.05$ & $<01$ & 0.056 & 0.933 & -0.684 & 0.249 \\
\hline & & $30 \mathrm{kDa}$ & 4 & 0.455 & NS & 0.1 & & & & \\
\hline
\end{tabular}

Statistically meaningful values are shown in bold.

NS, Not significant

*20\% Initial sample was under the detection limit.

$* * 40 \%$ Initial sample could not be measured due to laboratory accident. 
Table 3. Ranges and averages of daily growth $(\mu)$, grazing mortality $\left(M_{\mathrm{g}}\right)$, lysis mortality $\left(M_{\mathrm{v}}\right)$,

\begin{tabular}{|c|c|c|c|c|c|c|c|c|}
\hline \multirow[b]{2}{*}{ Bacterial RQ type } & \multicolumn{2}{|c|}{$\mu\left(d^{-1}\right)$} & \multicolumn{2}{|c|}{$M_{\mathrm{g}}\left(\mathrm{d}^{-1}\right)$} & \multicolumn{2}{|c|}{$M_{\mathrm{v}}\left(\mathrm{d}^{-1}\right)$} & \multicolumn{2}{|c|}{$M_{\mathrm{g}+\mathrm{v}}\left(\mathrm{d}^{-1}\right)$} \\
\hline & $\begin{array}{c}\text { Range } \\
\text { (Min - Max) }\end{array}$ & Average \pm SD & $\begin{array}{c}\text { Range } \\
\text { (Min - Max) }\end{array}$ & Average \pm SD & $\begin{array}{c}\text { Range } \\
\text { (Min - Max) }\end{array}$ & Average \pm SD & $\begin{array}{c}\text { Range } \\
\text { (Min - Max) }\end{array}$ & Average $\pm \mathrm{SD}$ \\
\hline RQ & $1.05-2.42$ & $1.57 \pm 0.75$ & $0.46-0.74$ & $0.64 \pm 0.13$ & - & 0.69 & $1.12-2.16$ & $1.48 \pm 0.59$ \\
\hline UQ & $1.38-1.77$ & $1.53 \pm 0.21$ & $0.27-2.07$ & $1.10 \pm 0.67$ & $-0.94-1.47$ & $0.27 \pm 1.70$ & $1.13-1.73$ & $1.45 \pm 0.30$ \\
\hline MK & - & - & $0.11-0.60$ & $0.36 \pm 0.36$ & - & - & - & - \\
\hline UQ-8 & $1.20-2.96$ & $2.07 \pm 0.73$ & $0.54-1.59$ & $0.91 \pm 0.49$ & $1.10-1.55$ & $1.33 \pm 0.33$ & $1.18-2.77$ & $1.93 \pm 0.67$ \\
\hline UQ-10 & $1.64-2.52$ & $2.08 \pm 0.63$ & $0.81-1.12$ & $1.00 \pm 0.17$ & - & - & $1.77-2.56$ & $2.17 \pm 0.56$ \\
\hline MK-8 & - & - & - & 0.53 & - & - & - & - \\
\hline MK-9 & - & 1.40 & - & 0.59 & - & - & - & 1.30 \\
\hline MK-9( $\left.\mathrm{H}_{8}\right)$ & - & 0.24 & $-0.25-0.93$ & $0.35 \pm 0.59$ & - & - & - & 0.32 \\
\hline
\end{tabular}

SD, Standard Deviation 
Table 4. Ranges and averages of daily carbon production $(C P)$, grazing loss $(G L)$, lysis loss

$$
(L L), \text { total losses }(T L) \text { and }
$$

net carbon production $\left(C P_{\text {net }}\right)$

\begin{tabular}{|c|c|c|c|c|c|c|c|c|c|c|}
\hline \multirow[b]{2}{*}{ Bacterial RQ type } & \multicolumn{2}{|c|}{$\begin{array}{c}C P \\
\left(\mu \mathrm{g} \mathrm{C} \mathrm{L}^{-1} \mathrm{~d}^{-1}\right)\end{array}$} & \multicolumn{2}{|c|}{$\begin{array}{c}G L \\
\left(\mu g \mathrm{C} \mathrm{L}^{-1} \mathrm{~d}^{-1}\right)\end{array}$} & \multicolumn{2}{|c|}{$\begin{array}{c}L L \\
\left(\mu \mathrm{g} \mathrm{C} \mathrm{L}^{-1} \mathrm{~d}^{-1}\right)\end{array}$} & \multicolumn{2}{|c|}{$\begin{array}{c}T L \\
\left(\mu \mathrm{C} \mathrm{L} \mathrm{L}^{-1} \mathrm{~d}^{-1}\right)\end{array}$} & \multicolumn{2}{|c|}{$\begin{array}{c}C P_{\text {net }} \\
\left(\mu g C^{-1} d^{-1}\right)\end{array}$} \\
\hline & $\begin{array}{c}\text { Range } \\
\text { (Min - Max) }\end{array}$ & $\begin{array}{l}\text { Average } \\
\pm \mathrm{SD}\end{array}$ & $\begin{array}{c}\text { Range } \\
\text { (Min - Max) }\end{array}$ & $\begin{array}{l}\text { Average } \\
\pm \mathrm{SD}\end{array}$ & $\begin{array}{c}\text { Range } \\
\text { (Min - Max) }\end{array}$ & $\begin{array}{l}\text { Average } \\
\pm \mathrm{SD}\end{array}$ & $\begin{array}{c}\text { Range } \\
\text { (Min - Max) }\end{array}$ & $\begin{array}{l}\text { Average } \\
\pm \mathrm{SD}\end{array}$ & $\begin{array}{c}\text { Range } \\
\text { (Min - Max) }\end{array}$ & $\begin{array}{l}\text { Average } \\
\pm \mathrm{SD}\end{array}$ \\
\hline RQ & $16.3-52.5$ & $37.4 \pm 18.8$ & $6.1-30.9$ & $18.5 \pm 17.5$ & - & 9.2 & $15.3-46.7$ & $36.2 \pm 18.1$ & $-3.1-5.8$ & $1.2 \pm 4.4$ \\
\hline UQ & $8.0-27.0$ & $19.7 \pm 18.8$ & $1.3-40.3$ & $19.4 \pm 19.7$ & $-18.3-6.9$ & $-5.7 \pm 17.8$ & $8.1-24.7$ & $18.3 \pm 8.9$ & $-0.9-4.9$ & $1.4 \pm 3.1$ \\
\hline MK & - & - & - & - & - & - & - & - & - & - \\
\hline UQ-8 & $5.1-18.5$ & $12.2 \pm 5.5$ & $1.3-9.5$ & $4.9 \pm 4.2$ & $3.6-7.2$ & $5.4 \pm 2.5$ & $4.9-17.3$ & $11.3 \pm 5.1$ & $0.2-1.8$ & $0.8 \pm 0.8$ \\
\hline UQ-10 & $10.9-16.8$ & $13.8 \pm 4.2$ & - & 7.4 & - & - & $11.7-17.1$ & $14.4 \pm 3.8$ & $-0.3--0.9$ & $-0.6 \pm 0.4$ \\
\hline MK-8 & - & - & - & - & - & - & - & - & - & - \\
\hline MK-9 & - & 5.8 & - & - & - & - & - & 5.4 & - & 0.4 \\
\hline MK-9 $\left(\mathrm{H}_{8}\right)$ & - & 0.6 & - & - & - & - & - & 0.8 & - & -0.2 \\
\hline
\end{tabular}

SD, Standard Deviation 
Table 5. Studies of simultaneous determination of grazing and viral lysis rates in freshwater systems

\begin{tabular}{|c|c|c|c|c|c|}
\hline Method & Grazing $\%$ potential & Lysis $\%$ potential & Location and water layer & Trophic status & Reference \\
\hline & production & production & & & \\
\hline \multirow[t]{3}{*}{ TC \& FVIC } & $81.8-108.0$ & $7.7-27.8$ & Lake Plußsee, Epilimnion & Eutrophic & Weinbauer \& Hofle 1998 \\
\hline & $2.9-27.6$ & $19.6-46.8$ & Lake Plußsee, Metalimnion & - & Weinbauer \& Hofle 1998 \\
\hline & $5.0-8.9$ & $38.4-97.3$ & Lake Plußsee, Hypolimnion & - & Weinbauer \& Hofle 1998 \\
\hline FLB \& FVIC & 50 & 25 & Ŕímov Reservoir, Surface water & Meso-Eutorphic & Šimek et al. 2006 \\
\hline \multirow[t]{2}{*}{ TC \& FVIC } & 10.3 & 6.4 & Lake Pavin, Epilimnion & Oligomesotrophic & Bettarel et al. 2003 \\
\hline & 8.4 & 15.6 & Lake Pavin, Epilimnion & - & Bettarel et al. 2003 \\
\hline \multirow[t]{2}{*}{ Tritiated thymidine labeled bacteria } & 58.2 & 26.3 & Lake Tanganyika, Upper water (Wet season) & Oligotrophic & Pirlot et al. 2007 \\
\hline & 88.5 & 39.6 & Lake Tanganyika, Upper water (Dry season) & - & Pirlot et al. 2007 \\
\hline CD \& FVIC & $78^{*}$ & $7.7^{*}$ & Lake Erie, Surface and Deep water & Eutrophic & Gobler et al. 2008 \\
\hline FLMB \& viral dilution \& FVIC & $18-63^{*}$ & $35-60 *$ & Lake Bourget, Surface layer & Mesotrophic & Jacquet et al. 2005 \\
\hline MD & 45.9 & 100.5 & Lake Loosdrecht, Surface layer & Eutrophic & Tijdens et al. 2008 \\
\hline \multirow[t]{3}{*}{ MD } & $37.3-76.5$ & ND & Lake Geneva, Surface layer & Mesotrophic & Personnic et al. 2009 \\
\hline & $18.2-56.8$ & ND & Lake Bourget, Surface layer & Mesotrochip & Personnic et al. 2009 \\
\hline & 5.3 & ND & Lake Annecy, Surface layer & Oligotrophic & Personnic et al. 2009 \\
\hline MD & $37.5-71.0$ & 56.2 & Lake Biwa, Epilimnion & Mesotrophic & This study \\
\hline
\end{tabular}

TC, theoretical caluculation; FVIC, frequency of visible infected cells; FLB, fluorescence labeled bacteria; CD, conventional dilution method; FLMB, fluorescence labeled micro-beads; MD, modified dilution method

*Grazing or lysis \% standing stock $\mathrm{d}^{-1}$

$\mathrm{ND}$, not determined 


\section{Figure legends}

3 Fig. 1. RQs concentration (A) and composition (B) of $100 \%$ samples at the beginning 4 experiments.

5 Fig. 2. Changes in growth $(\mu)$, grazing mortality $\left(M_{\mathrm{g}}\right)$, lysis mortality $\left(M_{\mathrm{v}}\right)$, and total 6 mortality $\left(M_{\mathrm{g}+\mathrm{v}}\right)$ rates of total bacteria (RQ) and major bacterial groups. An asterisk 7 indicates that the rate is statistically meaningful (see Table 2).

8 Fig. 3. Changes in carbon biomass $(C B)$, production $(C P)$, grazing loss $(G L)$, lysis loss $9 \quad(L L)$ and total losses $(T L)$ of total bacteria (RQ) and major bacterial groups. An asterisk 10 indicates that the rate is statistically meaningful (see Table 2).

\section{Appendix}

13 Fig. S1. Regression analyses of dilution experiments to estimate growth and mortality 14 raty 


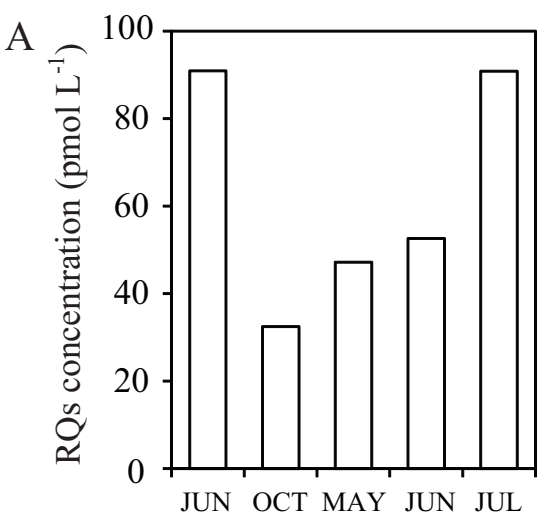

B

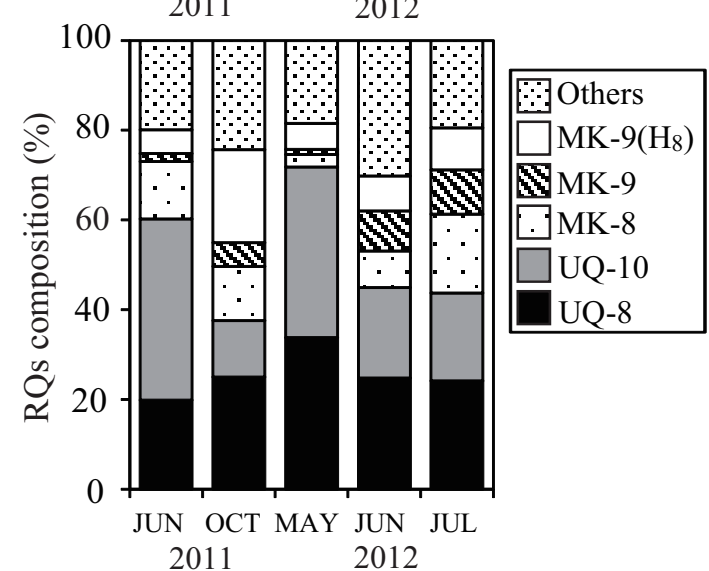

Takasu et al. Fig. 1 

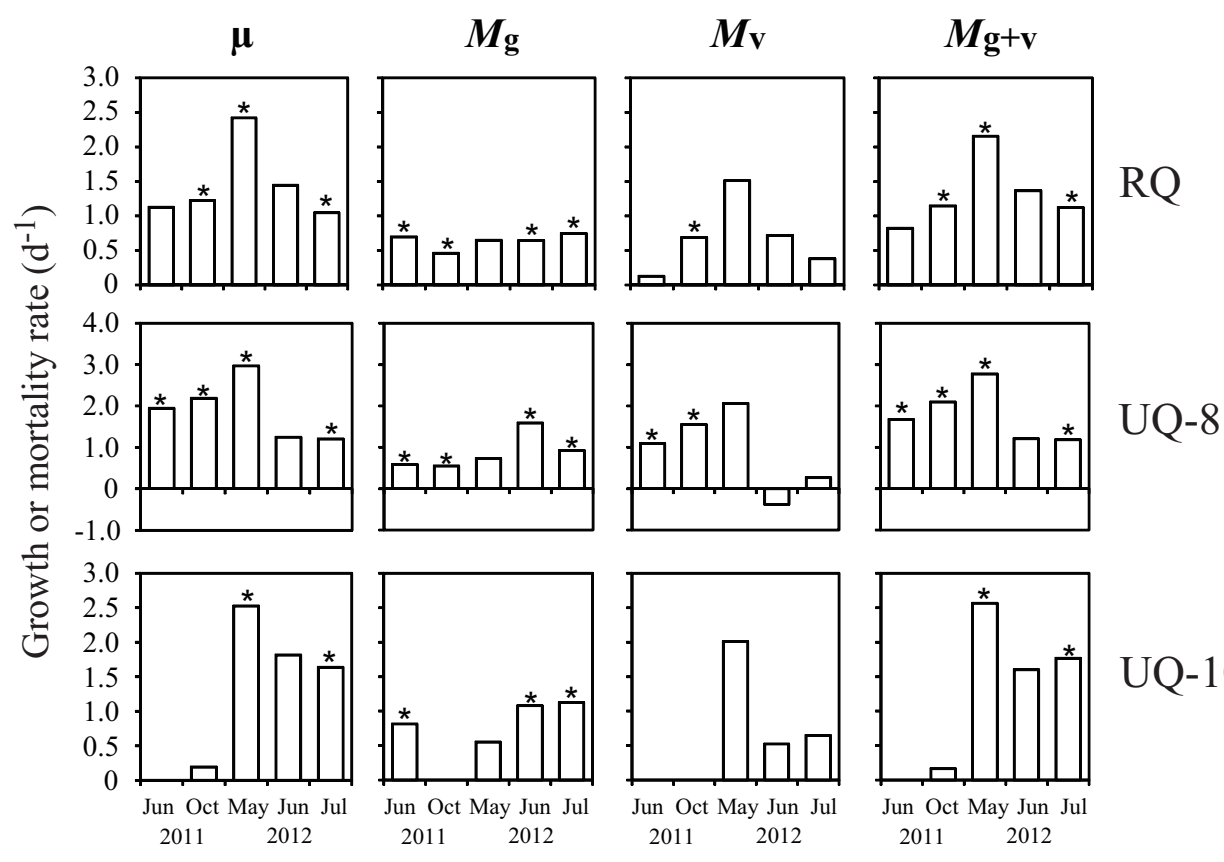


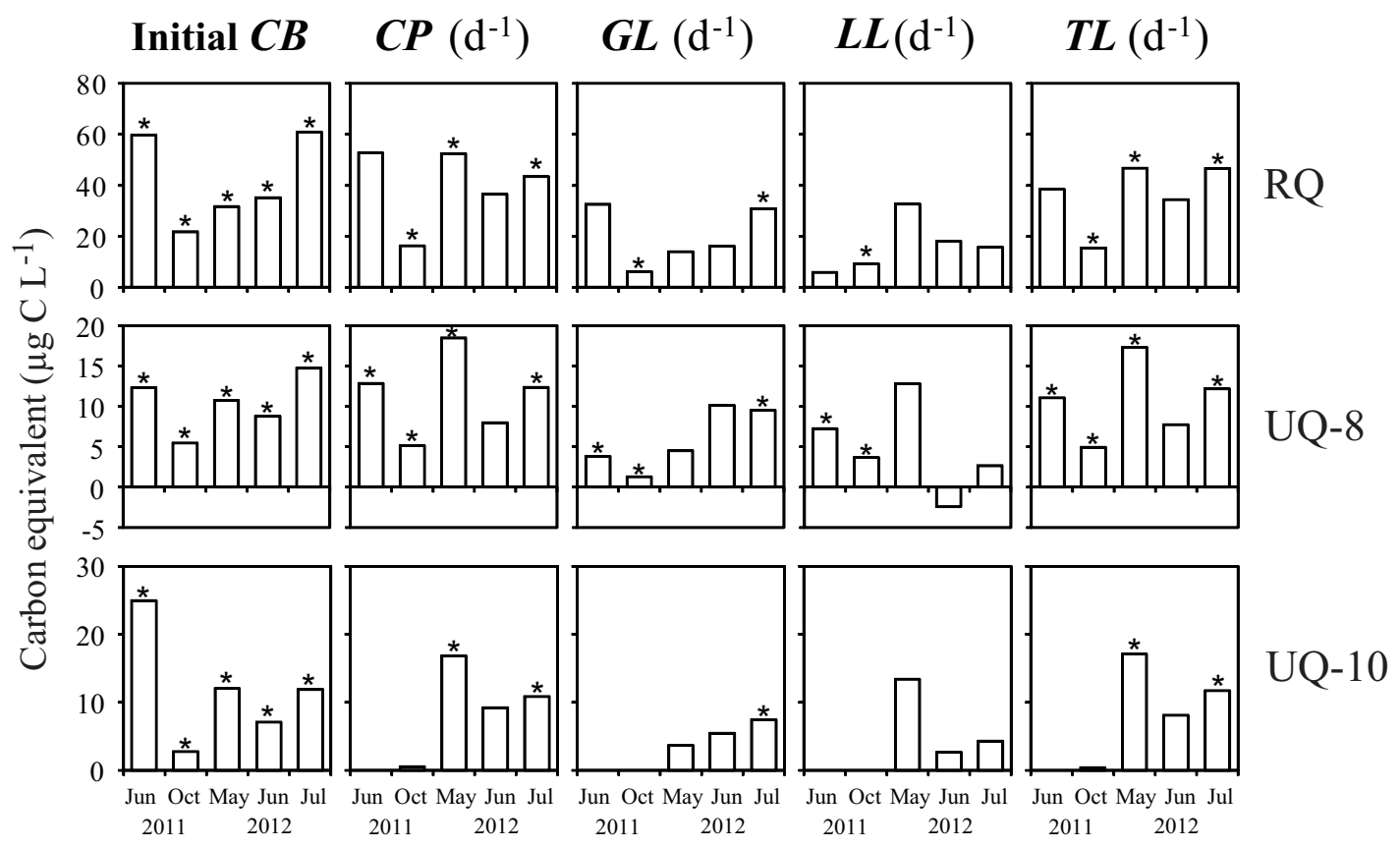


Jun. 2011
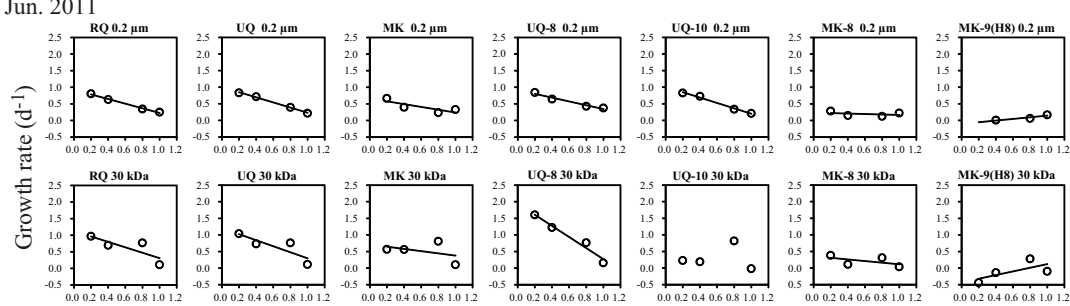

Oct. 2011
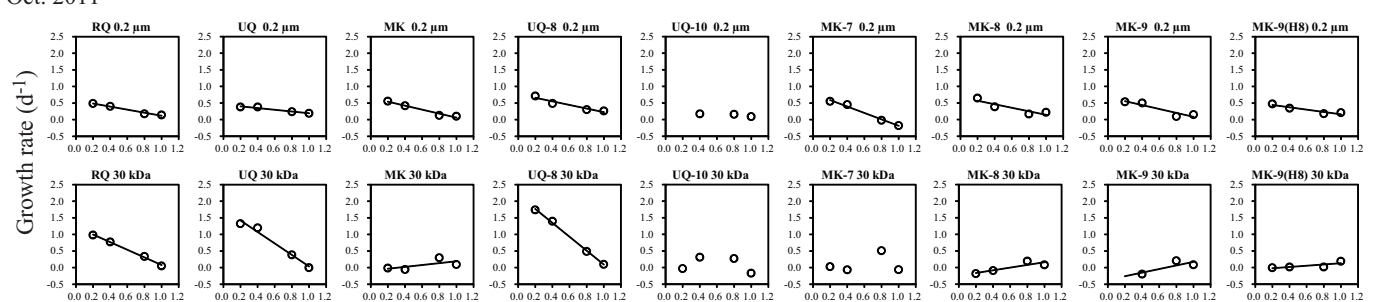

May 2012

Dilution factor (Proportion of $20 \mu \mathrm{m}$ filtrate)
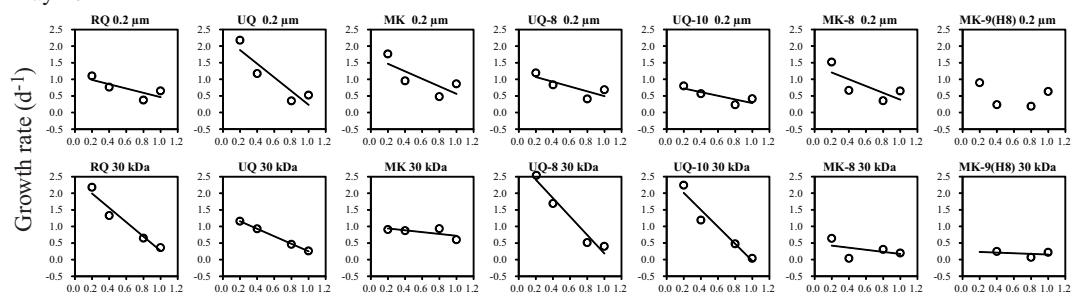

Dilution factor (Proportion of $20 \mu \mathrm{m}$ filtrate)
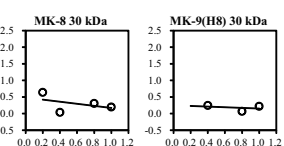
Jun. 2012

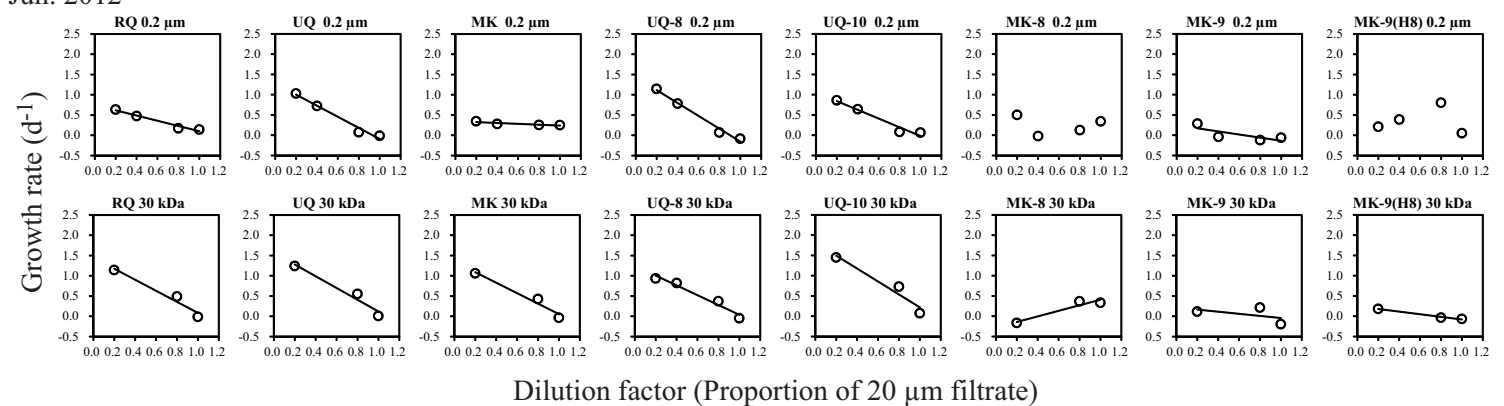
Jul. 2012
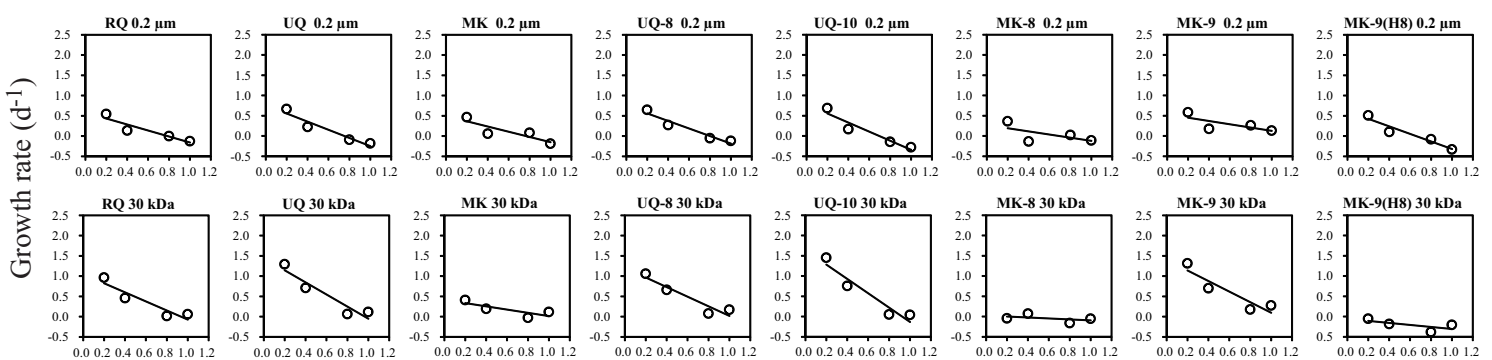

Dilution factor (Proportion of $20 \mu \mathrm{m}$ filtrate)

103

104

105

106

Takasu et al. Fig. S1 continued. 